\title{
THE THREE LEFT PERIPHERIES: BASES FOR A CARTOGRAPHIC STUDY OF BRAZILIAN PORTUGUESE 'LÁ'
}

\author{
AS TRÊS PERIFERIAS ESQUERDAS: \\ BASES PARA UM ESTUDO CARTOGRÁFICO DE 'LÁ' NO PORTUGUÊS BRASILEIRO
}

Bruna Karla Pereira ${ }^{1}$

Universidade Federal de Minas Gerais

\begin{abstract}
In this paper, we argue that Brazilian Portuguese 'lá' is directly merged in the functional specifier of different projections above IP, v/VP and NP. Under this assumption, we analyze three sentences where 'lá' does not support deictic locative meaning; instead it surfaces in rhetorical questions, negation and quantifier projections. Therefore, we hypothesize that 'lá' can be analyzed as merged in Spec,FocusP in both high and low peripheries and also in Spec, QP in the nominal structure.
\end{abstract}

Keywords: 'Lá'. Left periphery. Rhetorical questions. Negation. Quantification.

\section{Resumo}

Neste artigo, abordamos a hipótese segundo a qual 'lá', no português brasileiro, é inserido por 'merge' em spec de diferentes projeções funcionais localizadas acima do IP, v/VP e NP. Nesta perspectiva, analisamos três sentenças nas quais 'lá' não apresenta valor dêitico locativo; ao contrário, pertence a estruturas com questão retórica, negação e quantificação. Sendo assim, sugerimos que 'lá' pode ser analisado como especificador de FocusP nas periferias do IP e do v/VP e como especificador de QP na projeção nominal.

Palavras-chave: 'Lá'. Periferia esquerda. Questão retórica. Negação. Quantificação.

\section{INTRODUCTION}

In this paper, we argue that Brazilian Portuguese (BP) 'lá' is directly merged in the functional specifier of different functional projections in the cartography of NP, IP and v/VP. In order to support this claim, we investigate the following occurrences of 'lá':

(1) Rhetorical question:

Eu (lá) carrego (lá) desaforo pra casa?

I (lá) carry (lá) offense to-the home

Do I accept being offended by someone else?

\footnotetext{
${ }^{1}$ The author was supported by CAPES/PDEE to develop her research as a visiting $\mathrm{PhD}$ student at the University of Cambridge (UK), from January to December, 2010.
} 
(2) Negation:

A: Isso serve pra quê? (What is it for?)

B: Sei lá. // Know-1SG lá (I don’t know).

(3) Quantification:

Eu não tenho lá tanto dinheiro.

I not have lá much money

I haven't got such amount of money.

In these sentences, 'lá' does not support deictic locative meaning; instead it has the approximate senses indicated. Based on the functional specifier theory (CINQUE, 1999), we will suggest that this arises from the fact that 'lá' can be analyzed as specifier of different functional projections. Specifically, it seems that 'lá' surfaces either in the high and low clausal left peripheries or in the nominal left periphery.

Concerning this issue, the first section of this paper makes a review about the current studies on left periphery. Then, the second section describes the data given in (1) to (3) and discusses the analysis suggested by Martins (2010) for parallel structures in European Portuguese $^{2}$. Furthermore, this section depicts our hypothesis for analyzing sentences (1) to (3), which is different from Martins (2010)'s proposal. Finally, the last section is a brief conclusion.

\section{THE LEFT PERIPHERY}

\subsection{The IP periphery}

Based on Pollock (1989)'s seminal work about the splitting of IP in a number of different functional categories (TP, AspP e AgrP), Rizzi (1997) suggests that the CP also can be analyzed as a fine-grained structure through which it would be divided in a series of different functional projections.

The complementizer layer (CP), which is higher than IP, is the domain for topicalized and focalized items as well as for interrogative operators. As such, the categories that make up the CP "have an interpretive import (Wh, Neg, Top, Foc, ...): they determine the interpretation of the category bearing them" (RIZZI, 1997, p. 282).

Accordingly, the complementizer system supports "the interface between a propositional content (expressed by the IP) and the superordinate structure (a higher clause or, possibly, the articulation of discourse, if we consider a root clause)." (RIZZI, 1997, p. 283). As a

\footnotetext{
${ }^{2}$ This paper aims at developing a more proper discussion than the one that we developed in Pereira (2009) about the parallel between BP and EP data. We also hope to present more plausible solutions to the problems faced there concerning the attempt to apply Martins (2010)'s proposal to BP.
} 
result, CP expresses border line information between external (discourse) and internal (IP) dimensions of a sentence: "one facing the outside and the other facing the inside." (RIZZI, 1997, p. 283).

On one hand, concerning discursive information, $\mathrm{CP}$ expresses the clausal force (ForceP), i.e., the interrogative, declarative, exclamative, relative or adverbial status of the clause. On the other hand, concerning structural (IP) information, the choice of the complementizer specifies the finiteness (FinP) in the inflectional system. For instance, 'for' merged in Fin ${ }^{\circ}$ triggers an infinitival form (4).

(4) ...for John to leave tomorrow (RIZZI, 1997, p. 301).

In addition to Force-Finiteness system, Topic-Focus system constitutes the IP left periphery as well. According to Rizzi (1997, p. 285), topic is a clause-initial item, which carries given information and which is usually set off by a "comma intonation", as in the following example:

(5) O carro, o João comprou ele de segunda-mão.

the car, the João bought it of second-hand

The car, João bought it by second-hand.

In contrast, focalized items can be either clause-initial (6) or realized in situ (7), and, differently from topic, focus carries new information:

(6) O CARRO, o João comprou (não a casa). THE CAR, the João bought (not the house) It was the car that João bought not the house.

(7) O João comprou O CARRO (não a casa). The João bought THE CAR (not the house) It was the car that João bought not the house.

In addition to nominal elements, Focus is the position for Wh-operators, which are incompatible with focalized items, since both the latter and the former compete for the same position.

(8) a. *A chi IL PREMIO NOBEL dovrebbero dare? (RIZZI, 1997, p. 298).

To whom THE NOBEL PRIZE should they give?

b. *IL PREMIO NOBEL a chi dovrebbero dare? (RIZZI, 1997, p. 298).

THE NOBEL PRIZE to whom should they give?

Furthermore, Rizzi (1997) claims that if TopP and FocP are activated, they intervene between ForceP and FinP. In contrast, ForceP and FinP are always projected and occupy the terminal positions in the $\mathrm{C}$ domain, according to the following representation: 


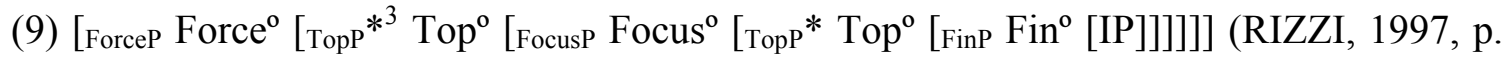
297).

\subsection{The VP periphery}

In the previous section, we observed that the external IP area (CP) is made up by a rich and complex space with different functional layers. In contrast, in this section, we will observe that the internal IP area, which is placed immediately above $\mathrm{v} / \mathrm{VP}$, also provides a structure bearing CP-like functional categories.

Belletti (2003) develops an analysis on "the fine-grained structural cartography of the clause's (IP) internal low area" (BELLETTI, 2003, p. 17) and shows that this area "displays a significant resemblance to the left periphery of the clause" (BELLETTI, 2003, p. 17) in the extent that it makes available a Focus position between two or more Topic projections. Accordingly, v/VP bears a left peripheral domain akin to the $\mathrm{CP}$ one.

In order to develop this hypothesis, Belletti (2003) calls attention to the properties of what should be an internal focus position in free inversion (FI) constructions with post-verbal subject. Free inversion structures have the following features: it occurs in null subject languages and it is an internal IP phenomenon. Therefore, in FI, the post-verbal subject is low since the verb moves past the subject without reaching the CP domain.

Some reasons are given for that: Firstly, post-verbal subjects follow low adverbs (10a). In fact, (10b) shows that the NP subject can not move to a higher position than the one the adverb is in.

(10) a. ? Capirà completamente Maria (BELLETTI, 2003, 19). will understand completely Maria

b. * Capirà Maria completamente (BELLETTI, 2003, 19). will understand Maria completely

Secondly, the post-verbal position is not an extraction domain. For instance, wh-extraction is not allowed (11). From this fact, post-verbal subject position can be identified with FocusP rather than with an argument position.

(11) a. Ha telefonato il direttore del giornale al presidente (BELLETTI, 2003, 20).

has phoned the director of the newspaper to the president

b. ?? Il giornale di cui ha telefonato il direttore al presidente (BELLETTI, 2003, 20).

the newspaper of which phoned the director to the president

After explaining the reasons why post-verbal subject is low in FI, Belletti (2003) develops a discussion on the interpretation of this element which differs from pre-verbal subject

\footnotetext{
${ }^{3}$ The stars indicate that topics are recursive.
} 
basically in new information and in emphasis. Therefore, $(12 \mathrm{Ba})$ with post-verbal subject is a proper answer for $(12 \mathrm{~A})$, but not $(12 \mathrm{Bb})$ with preverbal subject $(12 \mathrm{Bb})$.

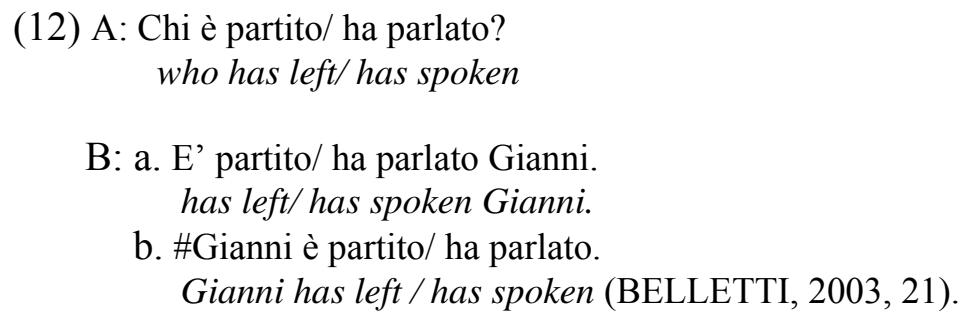

Briefly, "the focus interpretation of the postverbal subject should optimally come out of the syntactic configuration in which the subject DP is inserted. This naturally leads to the proposal that it should fill a low Focus position" (BELLETTI, 2003, 22). Thus, the low left v/VP periphery can be drawn as in the following diagram:

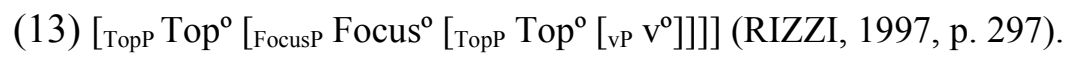

\subsection{The NP periphery}

In this section, we will summarize four features which make clausal and nominal structures symmetrical in relation to not only their internal configuration, but also their external periphery. Then, we will observe that the DP is decomposed in different functional categories just like the $\mathrm{CP}$ is.

The first feature is the distribution of grammatical functions. In (14), "the enemy" occupies the specifier position and displays the subject function of either VP (14a) or NP (14b) while "the city" displays the complement function of either $\mathrm{V}^{\mathrm{o}}$ (14a) or $\mathrm{N}^{\mathrm{o}}(14 \mathrm{~b})$.

(14) a. The enemy destroyed the city (ABOH et al., 2010, p. 782).

b. The enemy's destruction of the city (ABOH et al., 2010, p. 782).

The second feature is the presence of movement operations. In (15b), the DP 'the city', which used to be the complement of $\mathrm{N}^{\mathrm{o}}$ ('destruction of the city'), undergoes a movement to specifier position ('the city's destruction'). This operation is similar to the one undergone by the DP 'the city' (in 15a), which used to be the complement of $V^{o}$ ('destroy') before passivization.

(15) a. The city was destroyed by the enemy (ABOH et al., 2010, p. 782).

b. The city's destruction by the enemy (ABOH et al., 2010, p. 782).

The third feature is agreement. For instance, the agreement between possessor and possessed parallels the agreement between subject and verb (ABOH et al., 2010, p. 782). As a consequence, nominal structures would be made up by an internal AgrP (or InflP) 
system which is decomposed in several functional projections bearing possessives, demonstratives, quantifiers, adjectives (CINQUE, 1994), and so forth.

The fourth feature is the connection between discourse and structure. Like $\mathrm{C}$, which faces the internal (structural configuration: IP) and external (discursive configuration: speech act, topic-comment, focus-presupposition...) clausal dimensions, D also has this interface status.

On that account, the internal face of D would be identified with DfinP. Haegeman (2004, p. 235) claims that the "position that encodes (in)definiteness in the D domain [...] is parallel to Fin in the C domain". Accordingly, while FinP transforms a clause into an argument and determines if it is tensed or infinitival, DfinP transforms a noun into an argument and determines if it is definite or indefinite.

In addition, the external face of $\mathrm{D}$ would be identified in the constituent inversion, which leads to topicalization and hence interpretive changes. Thereupon, D would be split into a finer system of functional categories such as TopP, FocusP and DfinP.

According to Giusti (1996), in Italian, descriptive adjectives ('brutale') usually occupy a low position (16a). However, in a context in which everybody knows that the Martian invasion was brutal, either (16a), where 'brutale' surfaces in its basic position, or (16b), where 'brutale' moves to a higher position, are acceptable.

(16) a. La ultima vera brutale aggressione marziana al pianeta sara nel prossimo secolo. (GIUSTI, 1996, p. 120).

The last real brutal aggression Martian to the planet will be in the next century

b. Sappiamo tutti che la brutale ultima vera aggressione marziana al pianeta è la causa della distruzione dei dinosauri. (GIUSTI, 1996, p. 120).

We all know that the brutal last real aggression Martian to the planet is the cause of the destruction of the dinosaurs.

c. ?*la loro brutale ultima vera aggressione ...(GIUSTI, 1996, p. 120).

d. *la loro ultima brutale vera aggressione ...(GIUSTI, 1996, p. 120).

From Giusti (1996, p. 121)'s point of view, (16b) shows that TopP is the highest position in the nominal structure below the article, and $(16 \mathrm{c}, \mathrm{d})$ confirm this hypothesis because nothing besides the article can precede the topicalized adjective.

In sum, the features listed in this section provide a parallel between clausal and nominal structures roughly ${ }^{4}$ depicted below:

\footnotetext{
${ }^{4}$ According to Giusti (1996), the 'article' occupies the highest position in the structure of DP. However, the article can also be preceded by quantifiers (GIUSTI, 1991) or even by KP (Case Phrase) (COENE; D'HULST, 2002). As such, there are still higher positions above the article. Besides, it is not clear in
} 
TABLE 1: A parallel between clausal and nominal structures
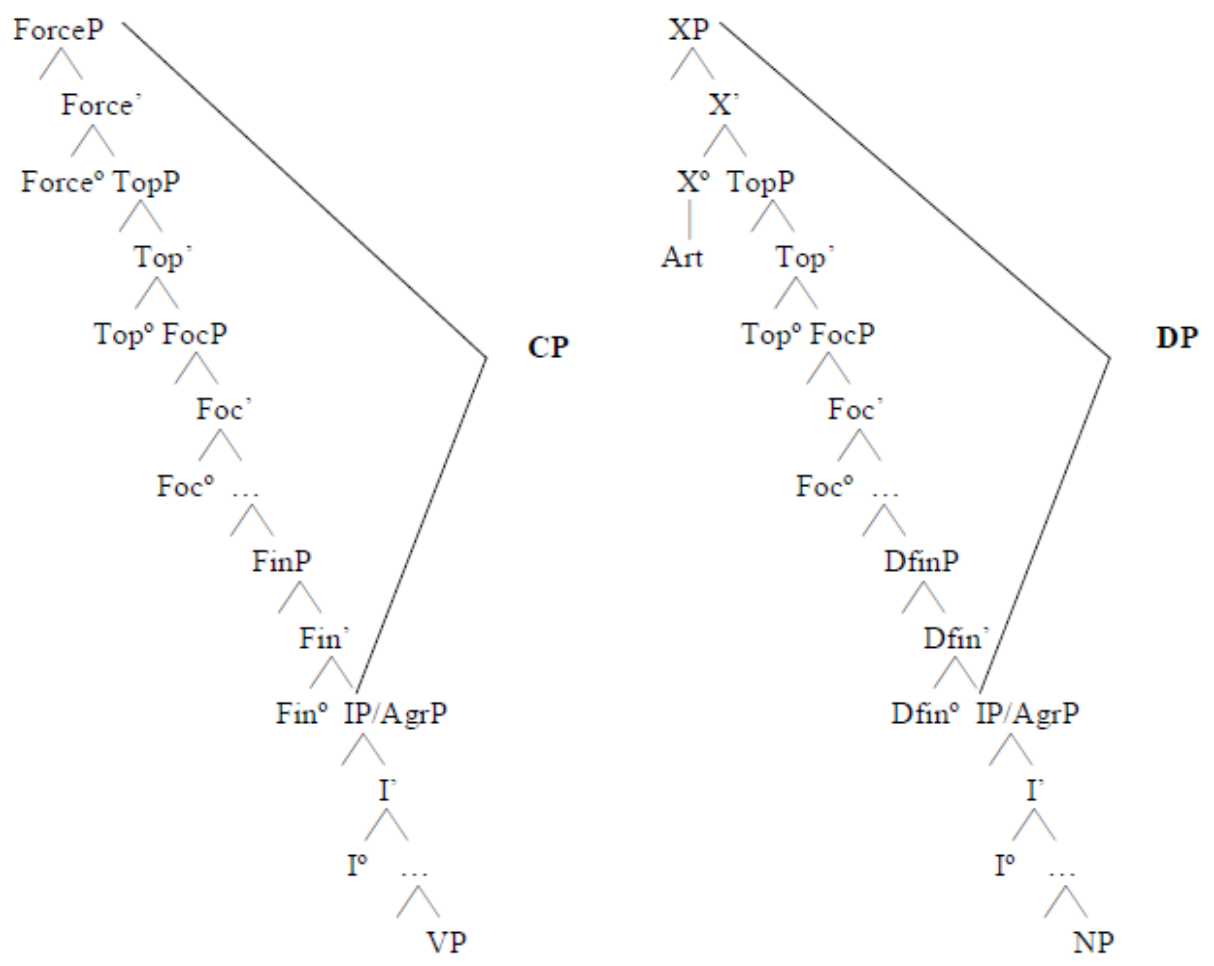

\section{3 ‘LÁ’ IN THE LEFT PERIPHERY}

This section reconsiders the BP data shown in the introduction of this paper and aims at developing the hypothesis according to which 'lá' is merged in spec of different functional projections of IP, VP and NP. Furthermore, in each subsection, we will discuss Martins (2010)'s proposal for analyzing parallel EP data.

\subsection{The IP periphery: 'lá' in Spec,FocusP}

We turn our attention now to (1a), a rhetorical question, which parallels EP (1b).

(1) a. Eu (lá) carrego (lá) desaforo pra casa?

I (lá) carry (lá) offense to my house (Do I accept being offended by someone else?)

b. Há lá coisa melhor que estar na praia?

Haegeman (2004)'s work what the exact position of DfinP is. If its position is parallel to FinP, when the nominal structure shows topic/focus items, the article should not be merged in DfinP (as it is suggested there), but higher. In fact, ForceP and FinP, originally "coalescing into a single head" (RIZZI, 2001, p. 287), are split into two distinct heads to account for topic/focus positions between them. The same reasoning might be applied to XP and DfinP as in table 1. 
is lá thing better than be-INFIN in-the beach (Could anything be better than staying on the beach?) (MARTINS, 2010, p. 16).

According to Martins (2010), since 'lá' is post-verbal, it should be in a lower position than the one hosting the verb. Therefore, she states that "Spec,TP in European Portuguese is a dedicated Utterance Time position [...] which can be made visible by speaker/utteranceanchored deictic locatives." (MARTINS, 2010, p. 18). Briefly, in her analysis, 'lá' is merged in Spec,TP, while subject and verb move respectively to Spec, $\Sigma \mathrm{P}$ and $\Sigma^{\circ}$.

Differently, BP 'lá' in (1a) can be preverbal. This signals that 'lá' would be actually in a higher position than TP. Thus, we hypothesize that 'lá' in (1) is merged in the CP domain, perhaps in Spec,FocusP, as 'lá' has strong pitch accent, is incompatible either with focalized elements or with some wh-items and allows recursive topics around it. These features will be explored in the following subsections.

\subsubsection{Focus and topic}

We observe that 'lá', in rhetorical questions, is prevented from co-occurring with focalized items:

(1) A: O João comprou um carro recentemente. João has recently bought a car).

B: i. Você quis dizer: O PAI DO JOÃO comprou um carro recentemente e não o João.

You mean: JOÃO'S FATHER has recently bought a car not João.

ii. O João lá comprou um carro? Foi o pai dele.

The João lá bought a car? was the father of-his. Has João bought a car? It was his father who did it.

iii. Lá um carro o João comprou? Aquilo é uma lata velha.

Lá a car the John bought? That is a tin old.

Has João bought a car? That looks like scrap iron.

iv. Lá o João comprou um carro? Foi o pai dele.

Lá the João bought a car was the father of-his.

Has João bought a car? It was his father who did it.

The DPs in italic do not allow focalized reading. They carry shared information available in discourse (1A); hence they receive topic interpretation. Particularly, rhetorical questions allow a wide range of different orders in their constituent sequence (1Bii-iv). Therefore, we claim that, while 'lá' stands in FocusP, the position of the phrases in italic is the result of movement to TopP positions either higher or lower than FocusP, according to the derivations presented in table 2 .

Furthermore, it seems to be obvious that, if a rhetorical question is made for making doubtful shared and hence non-new information, topicalization of the highlighted phrases is a more likely analysis than focalization. 
TABLE 2. Rhetorical questions: 'lá' in Spec,FocusP (high periphery)

(1) Bii. O João lá comprou um carro?

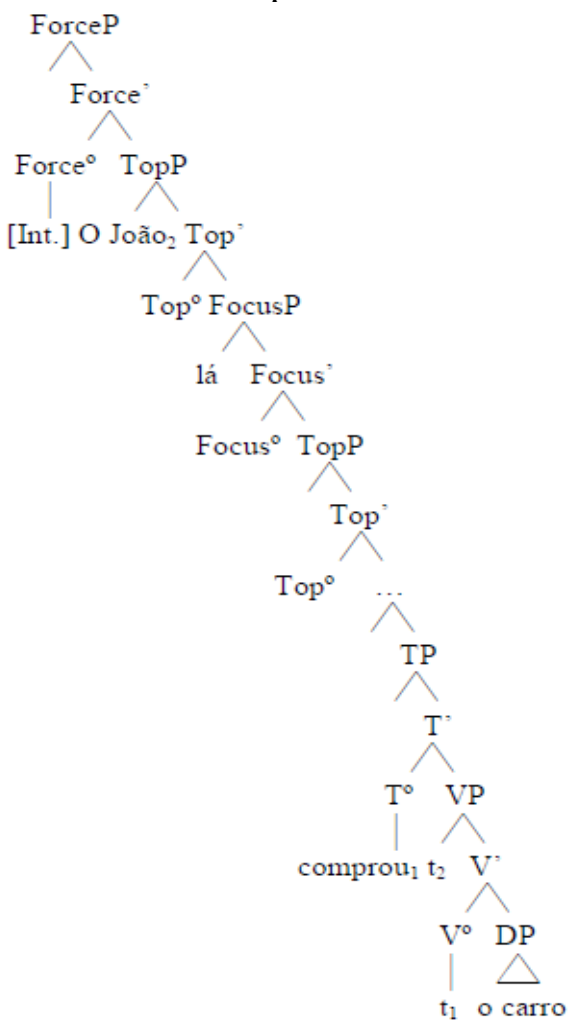

(1) Biii. Lá um carro o João comprou?

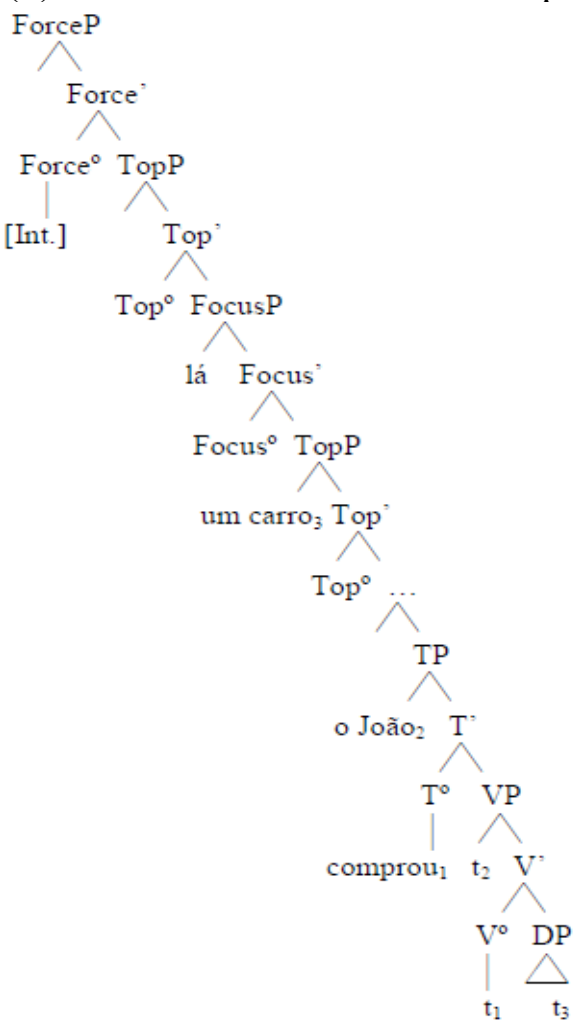

\subsubsection{Wh-items}

If we claim that 'lá' is incompatible with focalized items and, as a consequence, should be in Spec,FocusP, we wonder whether 'lá' can co-occur with Wh-items or not. This leads to a difficult judgment. In some cases, the compatibility is pretty clear $(1 \mathrm{c}, \mathrm{d})$; however, in other cases, 'lá' is banned from co-occurring with Wh-items (1e, f).

(1) c. Por que eu lá teria precedentes para duvidar de você?

Why would I have precedents to suspect you?

d. O que eu lá teria feito para ela se magoar?

What would I have made to be offensive with her?

e. *Como você lá comprou o carro?

How did you buy the car?

f. *Quem lá comprou o carro?

Who did buy the car? 
On one hand, the ungrammaticality of (1e, f) can be justified because 'como' and 'quem' compete with 'lá' for the Focus position. On the other hand, (1c) and (1d) are fully grammatical.

According to Rizzi (2001), adverbials like Italian 'perché' surfaces at a position which is higher than FocusP (proper to Wh-items) and lower than ForceP. This position is identified as Int(errogative)P(hrase). Like 'perché', 'por que' (1c) and 'o que' (1d) also could be analyzed as being merged in this projection. As a consequence, we would have a reason to show why 'lá' is compatible with these Wh-items.

Following Rizzi (2001), 'perché' is included in a special class of Wh-elements because, differently from the ordinary ones, it is allowed to co-occur with a focused item (1g) and it does not require I to $\mathrm{C}$ movement $(1 \mathrm{~h}, \mathrm{i})$.

(1) g. Perché QUESTO avremmo dovuto dirgli, non qualcos'altro? Why THIS we should have said to him, not something else? (RIZZI, 2001, p. 294)

h. * Come Gianni è partito? How Gianni left? (RIZZI, 2001, p. 292)

h'. Come è partito Gianni? How left Gianni? (RIZZI, 2001, p. 292)

i. Perché Gianni è venuto? Why Gianni has left? (RIZZI, 2001, p. 293)

Furthermore, when 'perché' co-occurs with a focused element, the "order is fixed: the focused element cannot precede perché" (RIZZI, 2001, p. 294) (1j). This indicates that this special class of Wh-items surfaces in a higher position than Focus.

(1) j. *QUESTO perché avremmo dovuto dirgli, non qualcos'altro? THIS why we should have said to him, not something else? (RIZZI, 2001, p. 294)

Besides, even though a focused element can not precede 'perché', a topicalized element can do it (1k). That is why IntP is a position between Force (phonetically null) and Focus.

(1) k. Il mio libro, perché, a Gianni, non glielo avete ancora dato?

My book, why, to Gianni, you still haven't given it to him? (RIZZI, 2001, p. 295)

As such, concerning BP example in (1c), it is possible to establish a correlation between 'perché' and 'por que', because 'por que' is also compatible with focused items (11) while ordinary Wh-items $(1 \mathrm{~m})$ are not.

(1) 1. Porque ISTO deveríamos dizer a ele e não outra coisa? m. *Como ISTO deveríamos dizer a ele e não outra coisa? 
Therefore, on one hand, in (1e, f), 'lá' compete with Wh-items for the same position: FocusP. On the other hand, in $(1 \mathrm{c}, \mathrm{d})$, this competition does not take place. It happens probably because "por que" and "o que" are merged in IntP. So, a possible explanation to justify why 'por que' and 'o que' are compatible with rhetorical 'lá' while other Wh-items are not is related to the fact that 'por que' and 'o que' occupy probably a higher position in the CP domain 5 .

\subsubsection{Is 'lá' a negation marker?}

A last word about 'lá' in rhetorical questions has to consider the following example discussed in Martins (2010).

(1) n. "Eu estou lá um pouco preocupado. Estou morto de preocupação". I am lá a little worried. Am dead of worry

I am not a little worried. I am worried sick. (MARTINS, 2010, p. 2).

According to Martins (2010), 'lá' in (1n) is different from 'lá' in (1b), repeated below for the reader's convenience.
(1) b. "Há lá coisa melhor que estar na praia?" (MARTINS, 2010, p. 16). is lá thing better than be-INFIN in-the beach Could anything be better than staying on the beach?

From her point of view, in (1n), 'lá' is a metalinguistic ${ }^{6}$ negation marker, because the sentence can be understood as a negative clause "Eu não estou um pouco preocupado" (I am not a little worried) and because this negative interpretation falls upon just "um pouco", but not upon the whole proposition.

However, in BP, (1n) is ungrammatical IF it is not pronounced with interrogative intonation. Thus, (1n) should be a rhetorical question and receive the same analysis given to (1a - d, B), according to which 'lá' is merged in Spec,FocusP of rhetorical questions.

\footnotetext{
${ }^{5}$ Furthermore, their own morphological nature is different from "como", "onde" e "quando", since these elements do not bear the interrogative marker "que" while "por que" and "o que" do.

${ }^{6}$ According to Horn (1985, p. 157), the main difference between marked (metalinguistic) and unmarked (descriptive) negation is that while the latter preserves a presupposition, the former challenges it. For instance, (i.b), which is the negative counterpart of (i.a), leaves the presupposition (i.c) untouched. In contrast, (ii) cancels the presupposition that (i.c) entailed by 'to manage'.

(i) a. John managed to solve the problem.

b. John didn't manage to solve the problem.

c. It was difficult for John to solve the problem. (HORN, 1985, p. 129).

(ii) John didn't MANAGE to solve the problem ...

it was quite easy for him to solve.

he was given the answer. (HORN, 1985, p. 130).

There are many different types of metalinguistic negation which is basically "a device for objecting to a previous utterance on any grounds whatever - including its conventional or conversational implicata, its morphology, its style or register, or its phonetic realization" (HORN, 1985, p. 121).
} 
The remaining issue is why $(1 \mathrm{a}-\mathrm{d}, \mathrm{B}, \mathrm{n})$ are understood as negation. The answer lies on a dedicated property of rhetorical questions: the polarity inversion. Following Han (1998, p. 1), "a rhetorical positive question has the illocutionary force of a negative assertion". Consequently, even if 'lá' were omitted, every sentence in (1a-d, B, n) still could be understood as negation. The direct conclusion from these facts is that 'lá' in (1a-d, B, n) is not structurally a negation marker at all; negation arises purely from the illocutionary force of rhetorical questions.

However, this is not true for example (2) in which 'lá' does not belong to any rhetorical question and DOES seem to be a negation marker, as it will be discussed in the following section.

\subsection{The VP periphery: 'lá' in Spec,FocusP}

From Martins (2010)'s point of view, 'lá' is a negation marker also in EP (2b), which parallels BP (2a).

(2) a. A: Isto serve pra quê? (What is it for?)

B: Sei lá. // Know-1SG lá (I don't know).

b. Quem foi? - Eu sei lá [...] (Who did it? I don't know) (MARTINS, 2010, p. 12).

Sentences (2) differ from (1) in many aspects. Firstly, (2) is not pronounced with interrogative intonation; secondly, 'lá' can not be preverbal; and thirdly, 'lá' is not omissible, because its elision would prevent the negative interpretation of the sentence. Thus, it seems that in (2), differently from (1), 'lá' is a negation marker'. Hence, we agree that 'lá' is a negation marker in (2), but we do not agree that it is merged in Spec,TP as it is suggested by Martins (2010).

In order to investigate the realization of 'lá' as a negation item, it is required to establish, first of all, a comparison between 'lá' and the types of post-verbal negation in BP. That is why the following subsections are aimed at: firstly, showing the differences between postverbal and preverbal negation (3.2.1); secondly, making a parallel between final negation and 'lá' (3.2.2); and thirdly, suggesting that 'lá' is the counterpart, in the low periphery, of final 'não' in the high periphery (3.2.3).

\subsubsection{Post-verbal negation}

Cyrino and Biberauer (2009) investigate the post-verbal negation in BP and suggest that final 'não' $(18,19)$ comprises two distinct categories with the same phonological

\footnotetext{
${ }^{7}$ It is important to say that the use of 'lá' as a negation marker seems to be restricted to some psychological verbs such as 'saber' (to know) and 'importar' (to mind).
} 
realization. As a result, there would be two distinct final 'não's surfacing in different structural positions.

[Não $\mathrm{N}_{1} \mathrm{~V}$

(17) a. Eu não/num comprei a casa.

I not bought the house (I didn't buy the house).

[Não 1 V Não $\left.{ }_{2}\right]$

(18) a. Eu não/num comprei a casa não.

I not bought the house not (I didn't buy the house).

[V Não ${ }_{3}$ ]

(19) a. Comprei a casa não.

Bought-1st the house not (I didn't buy the house).

(17) exemplifies the "real" negation in BP. Generally, the analysis given to pre-verbal 'não' follows the premises presented in Pollock (1989) according to which NegP is lower than TP. Thus, the pre-verbal position of 'não' ${ }_{1}$ is justified by its clitic features, for instance, the possibility of being phonologically reduced to 'num' (VITRAL, 1999; SOUZA, 2007). As a clitic, 'não' ${ }_{1}$ moves to a $\mathrm{T}^{\mathrm{o}}$ adjunct position, according to the following representation: 
TABLE 3: $\left[\mathrm{Não}_{1} \mathrm{~V}\right]$

(17) a. Eu não/num comprei a casa.

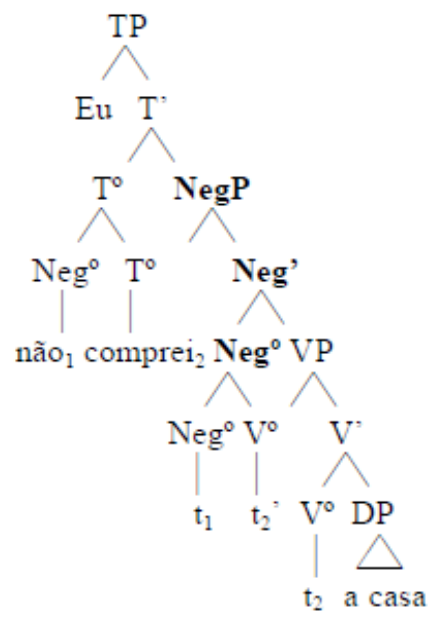

In contrast, (18) and (19) require another analysis, because 'não' surfaces in final position. Furthermore, from a semantic point of view, while 'não' ${ }_{1}$ triggers a propositional/descriptive negation, falling upon the truth value of the sentence, 'não' 2 and "não' 3 are depicted, respectively, as a reinforcing and a presuppositional ${ }^{8}$ negation particle (CYRINO; BIBERAUER, p. 2-3). That is why they are not considered as "real" negation markers.

Structurally, this discursive difference is reflected in the fact that 'não' 2 and 'não' 3 do not appear in Wh-interrogatives, according to the following examples:

(17) b. O que ele num/não ${ }_{1}$ fez?

What he not did

What didn't he do? (CYRINO; BIBERAUER, 2009, p. 3).

(18) b. *O que ele num/não ${ }_{1}$ fez não ${ }_{2}$ ? (CYRINO; BIBERAUER, 2009, p. 3).

(19) b. *O que ele fez não ${ }_{3}$ ? (CYRINO; BIBERAUER, 2009, p. 3).

\footnotetext{
${ }^{8}$ It is not clear why Cyrino \& Biberauer (2009) use the expression "presuppositional negation" for "não 3 '. According to Horn (1985), a presuppositional negation is the one which cancels a presupposition (i). (i) John didn't MANAGE to solve the problem. It was quite easy for him to solve. (HORN, 1985, p. 130). Nevertheless, there is no presupposition being canceled in (19a). According to Poletto (2008, p.7), "I will make use of the distinction between standard negation and presuppositional negation, meaning by [the latter] negative markers that can only occur under certain pragmatic conditions related to the speakers or addressee expectations". Therefore, it seems that the expression "presuppositional negation" has been used to refer to some type of non-neutral negation, though it has nothing to do with presupposition itself. If so, this expression has been used improperly when one considers the classic definition given by Horn (1985).
} 
Despite the discursive and syntactic similarities between 'não' 2 and 'não' 3 , Cyrino and Biberauer (2009) highlight that 'não' ${ }_{3}$, the one which surfaces without preverbal negation ('não' ${ }_{1}$ ), and 'não' ${ }_{2}$, the one which co-occurs with preverbal negation, are different items.

We will reproduce, in the following paragraphs, at least four among other differences pointed out by Cyrino and Biberauer (2009). Basically, they checked if 'não' 2 and 'não' 3 are: (i) omissible, (ii) available in yes/no questions, (iii) available in embedded clauses and (iv) compatible with negative polarity idioms.

Firstly, while 'não' 2 is omissible, 'não' 33 is not:

(18) c. Não/num comprei a casa (não ${ }_{2}$ ).

Not/NotCL buy-1SG-PAST the house (not) (I haven't bought the house).

(19) c. Comprei a casa $*(\text { não })_{3}$.

buy-1SG-PAST the house (not) (I haven't bought the house).

Secondly, while 'não' 2 surfaces in embedded clauses, 'não' ${ }_{3}$ does not:

(18) d. Ele disse que ele num/não $\mathbf{1}_{1}$ comprou a casa não . $_{\text {. }}$

He said that he notCL/not bought the house not.

He said that he hasn't bought a house. (CYRINO; BIBERAUER, p. 5)

(19) d. *Ele disse que ele comprou a casa não ${ }_{3}$ (CYRINO; BIBERAUER, p. 5)

Thirdly, while 'não' 2 surfaces in yes/no questions, 'não' ${ }_{3}$ does not:

(18) e. Você não/num comprou a casa não 2 ?

You not bought the house not

Haven't you bought the house? (CYRINO; BIBERAUER, p. 5)

(19) e. *Você comprou a casa não 3 ? (CYRINO; BIBERAUER, p. 5)

Fourthly, while 'não' 2 is compatible with negative polarity idioms, 'não' ${ }_{3}$ is not:

(18) f. A: - O João é rico (João is rich).

$\mathrm{B}:-\mathrm{O}$ que? Ele não tem um tostão furado não 2 .

What? He not has a cent with-a-hole not

What did you mean? He does not have a red cent (CYRINO;

BIBERAUER, p. 5).

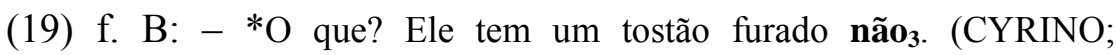
BIBERAUER, p. 5) 
Having explained these differences, Cyrino e Biberauer (2009) disagree with Cavalcante (2007) to whom 'não' 2 and 'não' ${ }_{3}$ would occupy the same position identified as Den(ial) $\mathrm{P}($ hrase) .

In a quick excursus on Cavalcante (2007)'s proposal, DenP is "a dedicated category that codifies discourse information related to either confirmation or denial of a previous presupposition"9 (CAVALCANTE, 2007, p. 128, our translation). Thereupon, "DenP is the position for both affirmative and negative pro-sentences (such as SIM, É and NÃO)"," (CAVALCANTE, 2007, p. 128, our translation), which are exemplified below:

(20) a. Não, eu num fiz.

b. No, I don't.

c. No, non l'ho fatto.

d. Non, je n'ai pas fait.

(CAVALCANTE, 2007, p. 122)
(21) a. Sim/É, eu fiz.

b. Yes, I did.

c. Si, l'ho fatto.

d. Oui/Si, j'ai fait.

(CAVALCANTE, 2007, p. 123)

Thus, Cavalcante (2007) assumes that the pro-sentence 'não' is an item placed outside the $\mathrm{CP}$ domain at DenP. The order [V Não] would be derived from the whole CP movement to another extra-sentential position (TopP) higher than DenP. Therefore, both 'não' ${ }_{3}$ and 'não' 2 would receive the same analysis.

Nevertheless, according to Cyrino and Biberauer (2009), this proposal does not account for the discrepancies showed in realizations of 'não' 2 and 'não' ${ }_{3}$, which are, in the following sequence, fully and loosely integrated to the clausal spine (CYRINO; BIBERAUER, 2009, p. 7). This hypothesis suggests that 'não' ${ }_{3}$ should be analyzed as part of the CP domain and 'não' 2 as part of the IP domain, contrary to Cavalcante (2007)'s proposal.

Cyrino and Biberauer (2009, p. 12) claims that 'não' 2 is in $\mathrm{Pol}^{\mathrm{o}}{ }^{11}$. Thus, 'não' 2 would be an agreement element matching the same properties available in NegP under TP. That is why $\mathrm{Pol}^{\circ}$ triggers TP movement to Spec,PolP (cf. the diagram standing for (18a) in table 4 below). As a result, "não' 2 makes part of constructions which "necessarily involve polarity emphasis (natural in emphatic negation and presupposition contexts)" (CYRINO; BIBERAUER, 2009, p. 11).

Nevertheless, Cyrino and Biberauer do not suggest a hypothesis for the derivation of sentences with 'não' ${ }_{3}$. They only claim that "não' 2 e "não' ${ }_{3}$ would be merged in distinct syntactic positions (CYRINO; BIBERAUER, 2009, p. 12).

\footnotetext{
9 "uma categoria específica responsável por codificar informações discursivas referentes à confirmação ou refutação de uma pressuposição anterior” (CAVALCANTE, 2007, p. 128).

10 "DenP é a categoria que aloja as profrases afirmativas e negativas (como SIM, É e NÃO) utilizadas em contextos de resposta a uma pergunta direta ou de assentimento ou denegação de uma declaração realizada anteriormente" (CAVALCANTE, 2007, p. 128).

${ }^{11}$ Cyrino and Biberauer (2009)'s proposal does not show evidence for analyzing 'não' 2 as $X^{\circ}$. The head status of 'não' ${ }_{1}$ is straightforward because it can be reduced to 'num', a clitic, but the same does not apply to 'não' ${ }_{2}$.
} 
According to Poletto (2008, p. 4-5), elements located in Neg4 (Italian NO, example (22)) "correspond to the same morpheme that is used for pro-sentence negation; [...] are located at the end of the clause; [...] are always specifiers, and they generally bear focus stress $[\ldots] "$. That is why they are located in Spec,FocusP.

(22) L'a mangià no (POLETTO, 2008, p. 5) he has eaten not (He is not eating).

Following Poletto (2008), one can suggest that 'não' 3 is merged in Spec,FocusP in the IP left periphery. Two main reasons justify this analysis. The first one is the incompatibility between 'não' ${ }_{3}$ and either Wh-interrogatives (19b) or focalized items (23).

(19) b. *O que ele fez não 3 ? (CYRINO; BIBERAUER, 2009, p. 3).

(23) a. *EU que vi não (CAVALCANTE, 2007, p. 141).

I who saw not (It was not I (the one) who saw it).

b. *ONTEM que eu fui não (CAVALCANTE, 2007, p. 141).

yesterday that I went not (It was not yesterday that I went there).

Thus, if it is true that 'não' ${ }_{3}$ is in Spec,FocusP, the order [V Não ${ }_{3}$ ] is justified with TP movement to Spec,TopP immediately above FocusP, according to the diagram standing for (19a) in table 4.

TABLE 4. [Não 1 V Não ${ }_{2}$ and [V Não 3 ]

(18) a. Eu não/num comprei a casa não. [Não ${ }_{1} \mathrm{~V}$ Não ${ }_{2}$ ]

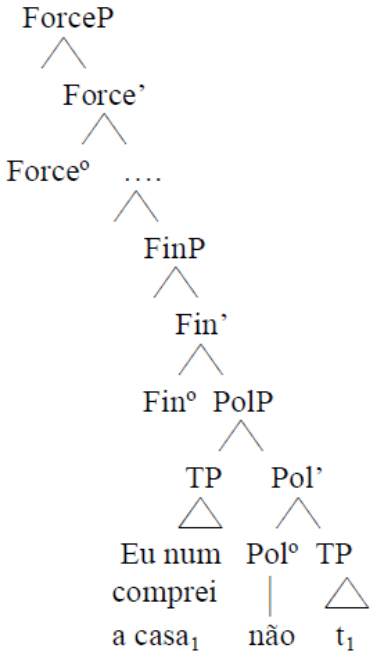

(19) a. Comprei a casa não. [V Não ${ }_{3}$ ]

ForceP

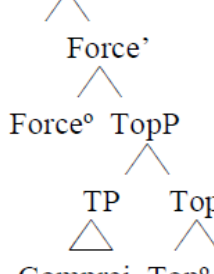

Comprei Top $^{\circ}$ FocP

a casa $_{1}$

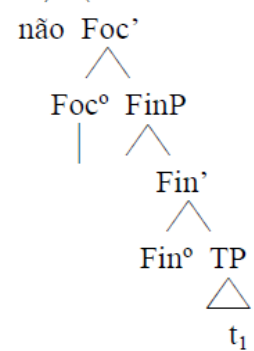


It is relevant to say that the derivation in (19a) is definitely more economical and less costly than the one proposed by Cavalcante (2007), since there is no need to generate two extrasentential categories (DenP and TopP) outside the CP domain to account for the position of 'não' 3 .

Briefly, in spite of the divergences between the available analyses, it is agreed that postverbal 'não' (either 'não' 2 or não' ${ }_{3}$ ) is placed above TP, generally in the CP domain. Since 'lá' also seems to be an element of negation in left periphery, we will establish a parallel between the properties of sentences containing final 'não' 3 and post-verbal 'lá'.

\subsubsection{A parallel between post-verbal 'lá' and final 'não'}

'Lá' shares three restrictions applied to 'não' 3 : it can not be omitted, it is not compatible with negative polarity idioms and it does not co-occur with 'não' ${ }_{1}$. Besides, both 'não' ${ }_{3}$ and 'lá' can be paraphrased by adverbs which entail non-neutral negation. However, 'lá' is adjacent to the verb while 'não' ${ }_{3}$ is not. These are the properties which will be discussed in the following subsections.

\subsubsection{Omission}

'Lá', just like 'não' 3 , can not be omitted.

(2) a. A: Isto serve pra quê? (What is it for?)

B: i. Sei lá [neg].

Know-1SG lá (I don’t know).

ii. Eu sei [aff]. Vou te explicar.

I Know. I go-FUT-1SG you explain

I know (what it is for). Let me explain it to you.

(19) c. Comprei a casa *(não $)_{3}$.

buy-1SG-PAST the house (not) (I haven't bought the house).

\subsubsection{Negative Polarity Items}

In addition, 'lá' is incompatible not only with negative polarity idioms (2c) but also with NPIs (2d), the latter being still acceptable with 'não' ${ }_{3}(19 \mathrm{~g})$.

(2) c. *Sei lá nadica de nada

Know-1sg lá little nothing of nothing (I know nothing about nothing).

d. *Eu sei lá nada disso.

I Know-1sg lá nothing of it (I know nothing about it).

(19) g. Sei nada disso não .

Know nothing of it not (I know nothing about it). 


\subsubsection{3 'Não' ${ }_{1}$}

Furthermore, both 'não' ${ }_{3}$ and 'lá' don't co-occur with NegP projection, i.e., with 'não' ${ }_{1}$ :

(2) e. *Não sei lá. Not know-1SG lá (I don’t know).

(19) h. *Não estudei não. Not study- PAST-1SG not (I haven't studied).

The expression "não sei o que lá" (not know-1SING the what lá = something (that the speaker do not know exactly whatever it is)) is generally used in noun positions such as external (24a) and internal arguments (24b) and also as a $\mathrm{P}^{\mathrm{o}}$ argument (24c):

(24) a. [Não sei o que lá] fez barulho à noite. [not know-1SING the what lá] maid noise at night Something (whatever it is) made a noisy sound last night.

b. A Maria comprou chinelo, calça, blusa e mais [não sei o que lá]. The Maria bought flip-flop, trouser, t-shirt and more [not know1 SING the what lá]

Mary bought a pair of flip-flops, a trouser, a t-shirt and something else.

c. O Tobias latiu com [não sei o que lá] que estava passando na rua.

The Tobias barked with [not know-1SING the what lá] that was passing in-the street.

Tobias barked because something (whatever it is) was going on in the street.

Therefore, "não sei o que lá" is more likely to be a nominal expression and hence it is not a counter-argument for the incompatibility between 'lá' and 'não ${ }_{1}$ ' exemplified in (2e).

\subsubsection{Paraphrases}

(2) A: Isto serve pra quê? What is it for?

B: a. Sei lá.

Know lá (I don't know).

b. Nem sei, pra te falar verdade.

Even know-1SG, to you(acc) speak

true

I don't know, to be honest.

c. Não sei.

Not know-1SG.

I don't know.
(25) A: Você estudou pra prova, não estudou?

You have studied for the exam. Haven't you?

B: a. Estudei não.

Studied-1SG not (I haven't studied).

b. Estudei nada.

Studied-1G nothing (I haven't studied).

c. Não.

No.

Let's suppose that $(2 \mathrm{~A})$ is said in a situation where the speaker B is a Biology teacher and the speaker $\mathrm{A}$ is a student. They are both in a science laboratory class at the moment when the student points to one of the experimental tools available and utters the question (2A). 
As such, $(2 \mathrm{Ba}, \mathrm{b})$ are not neutral negations since they convey the conversational implicature $^{12}$ according to which $\mathrm{B}$ was expected to know about the usefulness of that specific tool. Now, let's suppose that $(25 \mathrm{~A})$ is said in a situation where two students are having exams within few hours. Both of them should have studied for it. (25Ba, b) denies the affirmative utterance in $(25 \mathrm{~A})$. Therefore, $(2 \mathrm{Ba}, \mathrm{b})$ and $(25 \mathrm{Ba}, \mathrm{b})$ are not simply neutral negative answers like $(2 \mathrm{Bc})$ and $(25 \mathrm{Bc})$ are. In $(2 \mathrm{Bc})$ and $(25 \mathrm{Bc})$, the denial of a previous utterance is not necessarily entailed which means that they are simply informative and negative replies to a question.

Roughly, according to the data showed in (2) and in (25), using 'nem' (2Bb), 'lá' (2Ba), 'não' 3 (25Ba) and final 'nada' $(25 \mathrm{Bb})$, a non-neutral negation is conveyed. Therefore, just as 'lá' accepts a parallel with 'nem', 'não' ${ }_{3}$ also accepts a parallel with the negative adverbial 'nada' 13 in final position.

\subsubsection{Different positions}

Despite these many similarities, 'lá' differs from 'não' ${ }_{3}$ in the sense that, while 'lá' is adjacent to the verb (2f), 'não' ${ }_{3}$ surfaces in final (post-complement) position (19i').

\footnotetext{
12 According to Horn (1985, p. 121), "marked negation is not reducible to a truth-functional one-place connective with the familiar truth-table for negation, nor is it definable as a separate logical operator; it represents rather a device for registering objection to a previous utterance on any grounds whatever". As such, in (i), "John didn't manage to solve some of the problems" entails the conversation implicature according to which John didn't manage to solve all the problems. Then, this implicature is denied in the second clause "he managed to solve all of them", a contradictory negation.
}

(i) John didn't manage to solve SOME of the problems - he managed to solve ALL of them (HORN, 1985, p. 130).

Considering this, the examples $(25 \mathrm{Ba}, \mathrm{b})$ do object to a previous utterance. That is why they can be considered metalinguistic negation. However, $(2 \mathrm{Ba}, \mathrm{b})$ do not deny a previous utterance. So, they don't fit in the definition of metalinguistic negation. However, they can not be considered neutral negation either as they are different from $(2 \mathrm{Bc})$ in the sense that the speaker assumes a conversational implicature (i.e., that he should know what the tool is for) in $(2 \mathrm{Ba}, \mathrm{b})$ but not necessarily in $(2 \mathrm{Bc})$.

${ }^{13}$ Final 'nada' (iBb) contrasts strikingly with post-verbal 'nada' (iBa):

(i) A: Você estudou muito pra prova? (Have you studied hard for the exams?)

B: a. Eu *(não) estudei nada. I not study-PAST-1SG anything (I haven't studied anything).

b. Estudei nada. Study-PAST-1SG nothing (I studied nothing).

In (iBa), the emphatic negation falls upon the truth value of the sentence. It is a descriptive/propositional negation. Hence, 'nada' is a NPI under the c-command of 'não' ${ }_{1}$. That is why 'não ${ }_{1}$ ' can not be omitted. Differently, 'nada' in (iBb) is not under the c-command of 'não' at all.

Furthermore, final 'nada', exactly like 'não' ${ }_{3}$, seems be in the left periphery of IP, due to its final position (iiB) and also due to its use as non-neutral negation marker.

(ii) A: Você leu o livro pra prova de hoje? (Have you read the book for the exams that we are taking today?)

$\mathrm{B}$ : Li o livro nada. Fiquei à toa no final de semana.

Read-1SG the book nothing. Stay-1SG lazy in-the end of week.

I haven't read anything. I messed around at this weekend.

Thus, although final 'nada' is homonymous to post-verbal 'nada', they show different syntactic distribution and also different semantic function. As such, final 'nada' would be probably merged in FocusP position, just like 'não' 3 , followed by IP-raising to a TopP higher than FocusP. 
(2) f. Sei lá pra quê que isso serve (I don't know what it is for).

f'. * Sei pra quê que isso serve lá. // Know-1sg for what that it is used lá

(19) i. Sei não 3 pra quê que isso serve (I don't know what it is for).

i'. Sei pra quê que isso serve não ${ }_{3}$. //Know-1sg for what that it is used not.

A brief analysis of these five features reaches some important conclusions. Firstly, the two first properties mentioned, i.e., the fact that 'lá' is not omissible and is not compatible with NPIs suggest, respectively, that 'lá' determines the negative polarity of a sentence and that 'lá' disputes the same positon with NPIs. Besides, the third property, i.e., the incompatibility of 'lá' with 'não' ${ }_{1}$ indicates that 'lá' does not depend upon 'não' ${ }_{1}$ to play a negation role. Moreover, the fourth property, that is, the paraphrase with 'nem' confirms the fact that 'lá' is a negation marker. Last, but not least, the fifth property, i.e., the adjacency to the verb suggests that 'lá' occupies a position lower than (and obviously different from) the one occupied by 'não' ${ }_{3}$. Now, the task is to find out exactly in which position 'lá' is merged.

\subsubsection{The position of negative 'lá': spec of low FocusP}

In this section, we will investigate some hypotheses for the analysis of 'lá' as a negative marker. As such, we need firstly check if it is feasible an analysis which considers 'lá' as a component of NegP. We will conclude that this is not the correct path to follow. Then, we will check if it can be viewed as an item belonging to the low left periphery.

We understand that NegP is the category where "real" (propositional) negation features are checked. In BP, while $\mathrm{Neg}^{\circ}$ would be the dedicated position for 'não'/'num', Spec,NegP would be the position for quantifiers, e.g., 'ninguém' (VITRAL, 1999). Likewise, in French, $\mathrm{Neg}^{\mathrm{o}}$ is for 'ne' while $\mathrm{Spec}, \mathrm{NegP}$ is for 'pas'. May it be possible that 'lá' is merged in the same position as 'pas'?

It is important to observe that 'pas', despite being grammaticalized as Spec,NegP, can still co-occur with 'ne' $\left(\mathrm{Neg}^{\mathrm{o}}\right)$. This is not the case of 'lá' which is prevented from co-occurring with 'não' (2g). Thus, in sentences where 'lá' is a negative marker, there is no NegP projection.

(2) g. *Não sei lá pra quê que isso serve.

Not know-1SG lá for what that this is used (I don't know what it is for).

Besides, it is worthy pointing out that a low adverbial, e.g., 'dejà' and 'toujours' can intervene between V and 'pas': 
(26) a. Il ne mangeait dejà pas de fruits où de legumes crus! ${ }^{14}$ He CL eat already not PART fruits or PART vegetables raw He didn't use to eat fruits or vegetables any more.

b. Mon fils a 2 ans il ne mange toujours pas seul. ${ }^{15}$ My son has 2 years he CL eat always not alone My son is 2 years old. He does not eat by himself at all.

In contrast, 'lá' must be adjacent to the verb, allowing only the intervention of a clitic:

(2) h. Importa-me lá o casamento dele.

Care me lá the marriage his (I don't care about his marriage)

h'. *Importa já lá o casamento dele.

Care already lá the marriage his (I don't care about his marriage)

Therefore, due to the adjacency between $\mathrm{V}$ e 'lá' and hence the impossibility of a low adverbial intervention between them, 'lá' seems to occupy a position lower than NegP and nearer to $\mathrm{v} / \mathrm{VP}$.

Synthesizing, if 'lá' is not placed neither in the CP domain, since it is post-verbal and adjacent, nor in NegP, since it is incompatible with $\mathrm{NegP}$, we are left with the v/VP periphery which seems to be an appropriate solution.

According to Belletti (2003), the available positions in the low left periphery are FocusP and TopP. These positions are activated in subject free inversion constructions, as in (27B):

(27) A: Você parece mais interessada na pensão que na separação.

You seem to be more interested in the pension than in the divorce.

B: Importa-me a separação (não estou interessada no dinheiro dele).

I care about the divorce (I am not interested in his money).

Therefore, in (27B), "a separação" would be merged in the internal IP left periphery. Let's now observe the co-ocurrence of 'lá' with post-verbal subject:

(2) i. A: Você parece ressentir a separação.

You seem to regret the divorce.

B: Importa-me lá a separação, estou cuidando da minha vida.

Care me lá the divorce, am-1SG taking-care of my life.

I don't care about the divorce, I am taking care of my own life.

\footnotetext{
${ }^{14}<$ http://www.nosbebesarrivent.org/viewtopic.php? $\mathrm{t}=1201 \& \mathrm{sid}=4 \mathrm{cb} 103044 \mathrm{e} 737 \mathrm{~b} 9 \mathrm{f} 7 \mathrm{ca} 7 \mathrm{~b} 1 \mathrm{af} 8921 \mathrm{~d} 66 \mathrm{e}>$. Accessed in: 16th March, 2010.

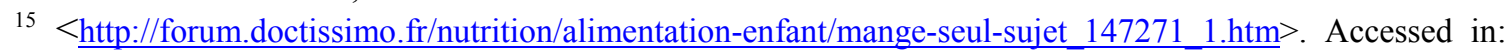
16th March, 2010.
} 
In (2iB), "a separação" carries given information. That is why it could be analyzed as Spec,TopP in the low left periphery. In contrast, 'lá', from a phonological point of view, is pronounced with emphatic intonation and, from a semantic point view, determines the negative polarity of the sentence. As a result, just like 'não' ${ }_{3}$, 'lá' could be analyzed as being part of Spec,FocusP in the low left periphery.

Concluding, the emphatic intonation, the expression of negation, the independence from 'não' ${ }_{1}$ and the incompatibility with NPI idioms lead us to believe that 'lá' would be the counterpart of 'não' ${ }_{3}$ in the v/VP left periphery. That is why it would occupy the low Spec,FocusP, according to the following derivations:

TABLE 5. Negation: 'lá' in Spec,FocusP (low periphery)

(2) i.B. Importa-me lá a separação.

(2B) Sei lá (pra quê que isso serve).
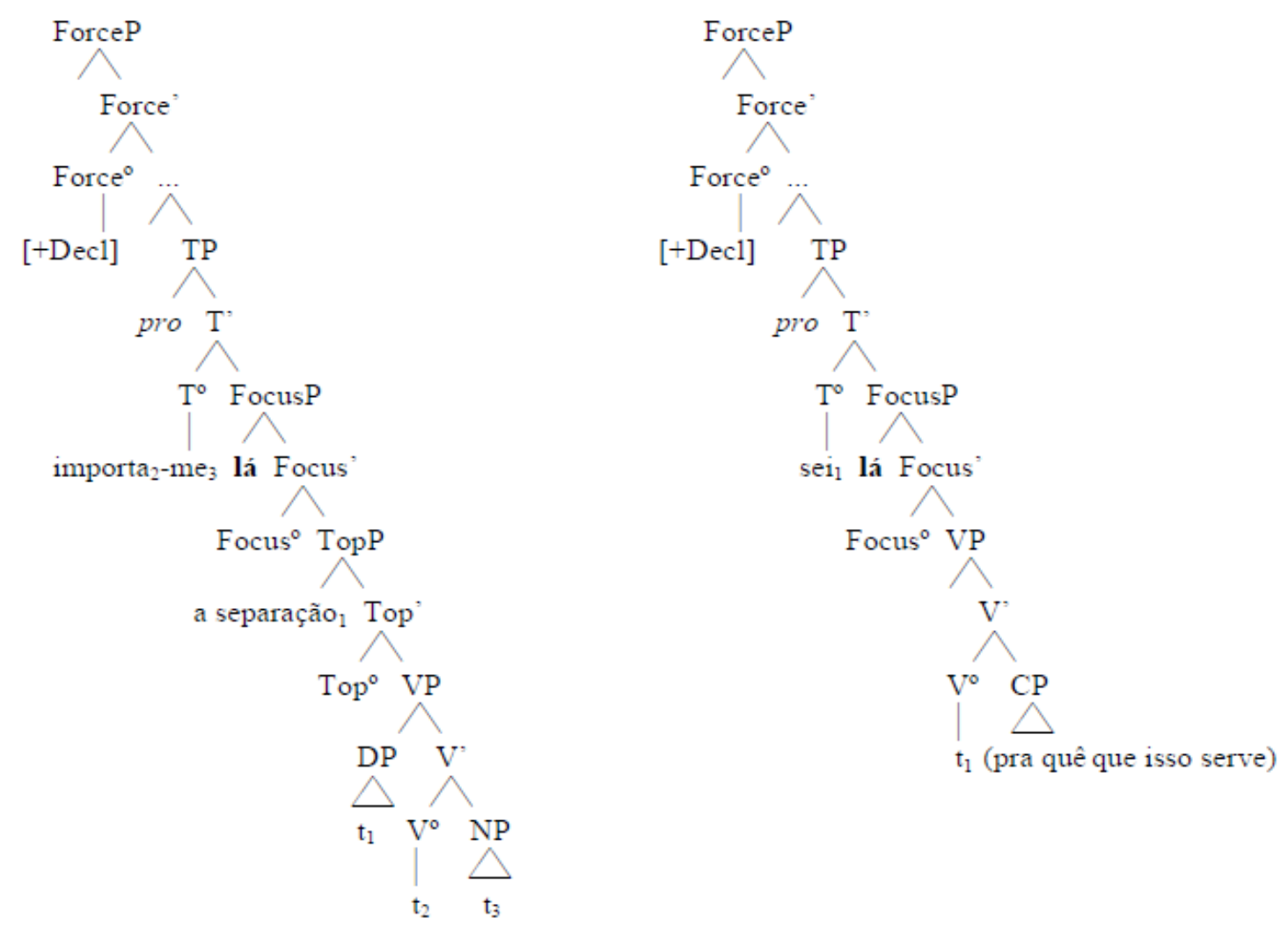

\subsection{The NP periphery: 'lá' in Spec,QP}

In this section, we analyze example (3):

(3) a. Eu não tenho lá tanto dinheiro.

I not have lá much money (I haven't got such amount of money). 
b. "Não gosto lá muito disso".

not like-1SG lá much of-that (I don't particularly like that) (MARTINS, 2010, p. 13).

Martins (2010, p. 13) suggests that European Portuguese (EP) 'lá' in (3b), which parallels BP (3a), is a negative polarity item (NPI) ${ }^{16}$. However, while 'lá' is compatible with positive polarity quantifiers $(3 \mathrm{a}, \mathrm{b})$, such as 'tanto' and 'muito', NPIs are not $(3 \mathrm{c})$ :

(3) c. *Eu não tenho nenhum tanto/muito dinheiro.

I not have any much money.

Thereupon, if 'lá' were a NPI ${ }^{17}$, it would be banned from co-occurring with positive polarity quantifiers; instead 'lá' in (3a) c-commands the quantifier 'tanto', which is the head of a QP.

According to Coene and D'hulst (2002), in reference to Shlonsky (1991 apud COENE; D'HULST, 2002, p. 11), the quantifier is a head which takes a DP/NP as complement. So, we understand that 'tanto' in (3a) is merged in a functional category QP which bears a $\mathrm{DP} / \mathrm{NP}$ as its complement.

Moreover, we can observe that 'lá', besides preceding a quantifier, ensures the checking features of Q even when the quantifier is not overt. This suggestion seems to be clearer when we deal with the following paradigm:

(3) d. Eu não tenho lá (todo) este luxo de casa.

I not have lá (all) this sumptuousness of house

I haven't got such a sumptuous house.

e. Ela não é lá (tanto) uma Brastemp ${ }^{18}$, mas serve.

She is not lá (much) a Brastemp, but serves

It is not that high quality machine, but it is still useful.

The possibility of inserting a quantifier in these constructions is not incidental. Through these sentences, the speaker undermines or denies some quality of an entity which was meant to be superior in some previous discourse. That is why 'not' falls upon the quantifers 'todo' and 'tanto'.

\footnotetext{
16 "Out of the picture will stay lá/cá as [...] polarity-sensitive words. As NPIs lá and cá are ..." (MARTINS, 2010, p. 13).

17 'Lá' differs from post-verbal NPIs also because, while 'lá' can surface without 'não' (ib), post-verbal NPIs can not (ia).

(i) a. O João *(não) tem nenhuma dificuldade em jogos.

The João not have-3SING any difficulty in sports. João does not face any trouble in sports.

b. O João tem lá (todas as) suas dificuldades nos jogos.

The João have-3SING (all the) his difficulties in sports. João has to handle (all his) troubles in sports. Obviously, (ib) is semantically different from (3a). The patter in (3a) is used to undermine something previously claimed as superior, while the patter in (ib) is used to confirm what was claimed as excessive. However, syntactically, 'lá' seems to be Spec,QP in both structures.

18 'Brastemp' is a very popular b rand of domestic appliances in Brazil.
} 
Besides the fact that 'lá' precedes a quantifier and co-occurs with it, some constituency tests, such as pronominalization ( $\left.3 \mathrm{f}, \mathrm{f}^{\prime}\right)$ and topicalization $(3 \mathrm{~g}, \mathrm{~g}$ ') show that 'lá' is probably in the spec of a quantifier, since 'lá' does not separate from $\mathrm{Q}$ in any of these tests.

(3) a. Eu não tenho [lá tanto dinheiro].

I not have lá much money (I haven't got such amount of money).

(3) f. Eu não tenho [isso]. I not have this (I haven't got it).

f'. *Eu não tenho lá isso. I not have lá this (I haven’t got it).

(3) g. Lá tanto dinheiro, eu não tenho.

Lá much money, I not have (Such amount of money, I haven't got it).

g'.*Tanto dinheiro, eu não tenho lá.

Much money, I not have lá (Such amount of money, I haven't got it).

Another property of these structures with 'lá' is that 'lá' is omissible and emphasized. Therefore, 'lá' in (3) shares with 'lá' in (1), which is the rhetorical questions marker, at least two characteristics. However, despite these similarities, they differ from each other in three main important aspects: firstly, 'lá' in (3) belongs to the DP while 'lá' in (1) belongs to the CP; secondly, 'lá' in (1) can be pre-verbal while this is not true for (3h); thirdly, 'lá' in (3i) can not surface in interrogatives.

(3) h. *Eu não lá tenho tanto dinheiro ${ }^{19}$.

I not lá have much money.

i. *Eu não tenho lá tanto dinheiro?

I not have lá much money.

Thereupon, we consider that the derivation of (3a), with 'lá' in Spec,QP, can be the following:

\footnotetext{
${ }^{19}$ With a contrastive reading (i), this sentence would be grammatical, but anyway 'lá' would not be a quantifier marker.

(i) Eu não lá (em casa) tenho tanto dinheiro, mas aqui (no banco).

I not lá (in house) have much money, but here (in-the bank).

I haven't got such amount of money there (at home), but here (in the bank).
} 
TABLE 6. Quantification: 'lá' in Spec,QP

(3) a. Eu não tenho lá tanto dinheiro.

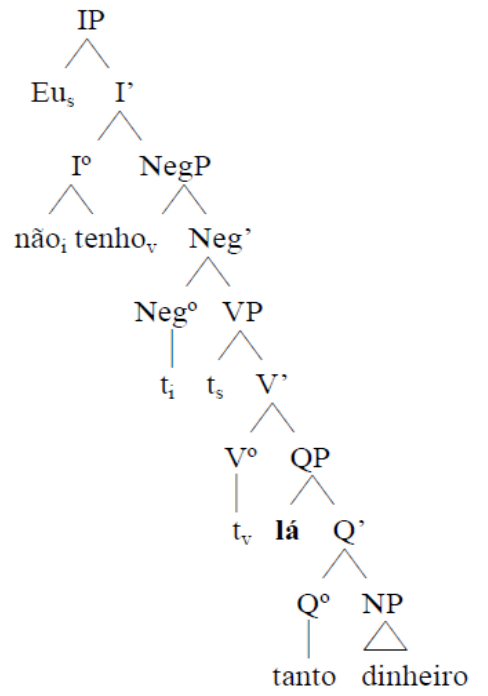

\section{FINAL REMARKS}

In this paper, we claimed that 'lá' can be analyzed as specifier of different functional categories placed in the NP, IP and VP peripheries.

This proposal differs from the one developed by Martins (2010) according to whom 'lá' is merged in Spec,TP. Although Martins (2010) assumes that 'lá' can be moved to the IPperiphery, for instance, in rhetorical questions, there is no specification about the position where 'lá' would be moved to and also there is no comment on the other left peripheries. In contrast, we worked towards providing analytical tools to account for sentences from (1) to (3).

Firstly, 'lá' in (1) would be Spec,FocusP in the high left periphery. In this case, 'lá' belongs to a sentence with interrogative intonation, is high pitch accented, can either precede or follow the verb, and can be omitted without changing the propositional content of the sentence. From this last property, it follows that the negative interpretation carried by (1) is not due to 'lá', but to the polarity inversion triggered purely by the illocutionary force of rhetorical questions.

Secondly, 'lá' in (2) would occupy the Spec,FocusP position in the low periphery. This position seems to be the counterpart of 'não' ${ }_{3}$ in the high periphery. In this case, 'lá' is adjacent and post-verbal. In addition, 'lá' is not omissible and is not compatible neither with NPIs nor with negative polarity idioms. Moreover, it is prevented from co-occurring with preverbal 'não'. Therefore, among all the three occurrences of 'lá' covered in this paper, only in (2) 'lá' could be properly considered a negation marker. Therefore, it is 
possible to claim that, only in (2), 'lá' conveys a semantic value beyond discursive emphasis $^{20}$.

Finally, 'lá' in (3) would be the specifier of a functional category expressing quantification in the DP structure. This implies that we reject the suggestion made by Martins (2010) according to which 'lá' would be a NPI. Our hypothesis is based mainly in the fact that 'lá' in (3) seems to make up the nominal structure "tanto dinheiro" whose head is a $Q^{\circ}$. This claim was supported by constituency tests such as pronominalization and topicalization.

To sum up, the analysis of 'lá' as specifier of functional projections in the cartography of $\mathrm{DP}, \mathrm{CP}$ and $\mathrm{v} / \mathrm{VP}$ is promising in the sense that it provides a unified analysis of a very diverse phenomenon. As such, the hypothesis is from now on open to be checked in the many other different structures with 'lá' in Brazilian Portuguese ${ }^{21}$.

\section{REFERENCES}

$\mathrm{ABOH}$, E. et al. DP-internal information structure: some introductory remarks. Lingua, Amsterdam, v. 120, n. 4, p. 782 - 801, 2010.

BELLETTI, A. Aspects of the low IP area. In: RIZZI, L. The structure of CP and IP: The cartography of syntactic structures. Oxford, New York: Oxford University Press, 2004. v. 2, p. 16-51.

CAVALCANTE, R. A negação pós-verbal no português brasileiro: análise descritiva e teórica de dialetos rurais de afro-descendentes. 2007. $161 \mathrm{f}$. Dissertation (Master in Linguistics) - Instituto de Letras, Universidade Federal da Bahia, Salvador, 2007.

CINQUE, G. Adverbs and Functional Heads: A Cross-Linguistic Perspective. New York: Oxford University Press, 1999.

. On the Evidence for Partial N-movement in the Romance DP. In: CINQUE et al. (Eds.). Paths Towards Universal Grammar: Studies in Honor of Richard S. Kayne. Washington: Georgetown University Press, 1994. p. 85 - 110.

COENE, M; D'HULST, Y. Introduction. In: (Eds). From NP to DP: the syntax and semantics of noun phrases. Amsterdam, Philadelphia: J. Benjamins Pub, 2003. v. 1, p. 1 33.

CYRINO, S.; BIBERAUER, T. Appearances are deceptive: Jespersen's cycle from the perspective of the Romania Nova and Romance-based Creoles. In: GOING ROMANCE, $23^{\text {rd }}$. Nice, 2009. 19 p. (handout).

\footnotetext{
${ }^{20}$ Being an optional discursive marker in (1) and (3), 'lá' does not change the propositional content of these sentences. That is why it can be considered an expletive.

${ }^{21}$ This research is in progress and is expected to be concluded by 2011.
} 
GIUSTI, G. Is there a FocusP and a TopicP in the Noun Phrase structure? Working Papers in Linguistics, Venice, v.6, n.2, p. 105-128, 1996.

. The categorial status of quantified nominals. Linguistische Berichte: Forschung, Information, Diskussion. Opladen, n. 136, p. 438 - 454, 1991.

HAEGEMAN, L. DP-periphery and clausal periphery: possessor doubling in West Flemish. In: ADGER, D.; CAT, C.; TSOULAS, G. Peripheries: syntactic edges and their effects. Dordrecht, Boston, London: Kluwer Academic Publishers, 2004. p. 211-240.

HAN, C. Deriving the interpretation of rhetorical questions. In: WEST COAST CONFERENCE ON FORMAL LINGUISTICS, $16^{\text {th }}$, 1998. Proceedings... Stanford: Center for the Study of Language and Information, 1998, p. 237-253.

HORN, L. Metalinguistic negation and pragmatic ambiguity. Language, 61, p. 121-174, 1985.

LAKA, I. The $\Sigma$ Projection. In: On the syntax of negation. New York: Garland Publishing, 1994. p. 63 - 103.

MARTINS, A. Deictic locatives, emphasis and metalinguistic negation. In: GALVES, C. et al., eds. Diachronic Syntax: Parameter Theory and Dynamics of Change. Oxford University Press, 2010. (forthcoming).

PEREIRA, B. A posição de 'lá' como marcador de negação no PB: um contraste com dados do PE. Revista Língua \& Literatura, Frederico Westphalen, n. 17, p. 235-260, 2009.

POLETTO, C. On negation splitting and doubling. In: NORMS WORKSHOP ON NEGATION. Oslo, 2008. 16 p. (handout).

RIZZI, L. On the position "Int(errogative)" in the left periphery of the clause. In: CINQUE, G.; SALVI, G. (Eds.). Current studies in Italian syntax: essays offered to Lorenzo Renzi. Amsterdam: Elsevier, 2001. p. 287 - 296.

. The structure of left periphery. In: HAEGEMAN, L. Elements of grammar: handbook of gererative syntax. Dordrecht, Boston, London: Kluwer Academic Publishers, 1997. p. 281-337.

SOUZA, L. Formas reduzidas de itens negativos no português brasileiro. 2007. $113 \mathrm{f}$. Dissertation (Master in Linguistics). Belo Horizonte: Universidade Federal de Minas Gerais, 2007.

VITRAL, L. A negação: teoria da checagem e mudança lingüística. DELTA, v. 15, n. 1, p. $57-84,1999$. 


\section{ACKNOWLEDGMENTS}

I am sincerely thankful to CAPES/PDEE for the financial support provided from January to December, 2010 when I had the opportunity to carry out this research at the University of Cambridge (UK). 